\title{
Massa Nutrien Maggot Lalat Tentara Hitam (Hermetia illucens) pada Media Yang Berbeda
}

\section{Maggot Nutrient Mass of Black Soldier Flies (Hermetia illucens) on Different Media}

\author{
Santi Nurdin', Andi Tenri Bau Astuti Mahmud ${ }^{2}$ \\ ${ }^{1}$ Program Studi Peternakan Fakultas IImu Pertanian Universitas Al Asyariah Mandar \\ E-mail : santipeternakan@gmail.com \\ ${ }^{2}$ Program Studi Peternakan Fakultas IImu Pertanian Universitas Al Asyariah Mandar \\ E-mail : anditenribauastuti@gmail.com
}

\begin{abstract}
ABSTRAK
Lalat tentara hitam merupakan jenis insekta yang yang cocok dimanfaatkan sebagai pakan karena mengandung protein tinggi dan ramah lingkungan, serta ketersediaannya berkesinambungan. Tujuan penelitian ini untuk mengoptimalkan produksi maggot meliputi massa protein, massa lemak kasar dan massa serat kasar. Waktu pelaksanakan pada bulan April - Juli 2019, yang bertempat di Program Studi Peternakan Universitas Al Asyariah Mandar (UNASMAN) untuk pemeliharaan dan analisis nutrisi di laksanakan di Lab. Kimia Pakan Fakultas Peternakan Universitas Hasanuddin (UNHAS). Rancangan penelitian yang digunakan yaitu Rancangan Acak Lengkap (RAL) dengan 3 media sebagai perlakuan dan 3 ulangan. Secara keseluruhan menghasilkan 9 unit percobaa. Perlakuan AO : amapas tahu 100\%, A1 : ampas tahu 50\% dan kotoran ayam 50\%, A2 : amapas tahu 75\% dan kotoran ayam 25\%. Hasil analisis sidik ragam menunjukkan penggunaan media yang berbeda bepengaruh nyata $(P<0.05)$ pada massa lemak kasar dan serat kasar, teatapi tidak berpengaruh nyata $(P>0.05)$ pada bahan kering dan protein kasar. Disimpulkan bahwa hasil produksi maggot lalat tentara hitam (Hermetia illucens) paling baik pada perlakuan A1 yaitu massa bahan kering $43.82 \mathrm{~g}$ dengan protein kasar $18.29 \mathrm{~g}$ dan lemak kasar $14.63 \mathrm{~g}$ serta serat kasar $4.62 \mathrm{~g}$.
\end{abstract}

Kata Kunci : Lalat tentara hitam, maggot, massa nutrisi, media.

\begin{abstract}
Black solider flies is a type insect that is suitable to be used as feed because it contains high protein and environmentally friendly, and its availability is contuous. The pepous of this research is to optimize production of maggots including protein mass and crude fibre mass. The reseach was conducted in April - July 2019, that is carried out in the Animal Husbandry Pogram Study for the rearing and the nutrition analysis was carried out in the Feed Chemistry Lab, Faculty of Animal Husbandry, UNHAS. This reseach was designed using a Completely Randomized Designed (CRD) with 3 media as a treatments and 3 replications. In total 9 unit experiment. Treatment A0: tofu waste 100\%, A1: tofu wast $50 \%$ and chicken faeces, tofu wast $75 \%$ and chicken faeces $25 \%$. The result of the analysis varians shows the use of different media significant effect $(P<0.05)$ on the crude fat mass and fibre crude, but not significant effect $(P>0.05)$ dry metter and crude protein. It was Concluded that the result maggot production of black solider flies (Hermetia illucens) better at he A1 is dry metter $43.82 \mathrm{~g}$ with crude protein $18.29 \mathrm{~g}$ and crude fat $14.63 \mathrm{~g}$ and crude fibre $4.62 \mathrm{~g}$.
\end{abstract}

Keywords : Black soldier flies, maggot, Nutrient mass, Media.

\section{PENDAHULUAN}

Ketersediaan bahan baku pakan Indonesia masih bergantung kepada impor, khususnya bahan pakan sumber protein baik nabati maupun hewani. Dampak impor bahan pakan yaitu usaha perunggas banayak yang 
terpuruk karena tingginya harga pakan. Sedangkan biaya pakan mencapai $70 \%$ untuk ayam pedaging dan $90 \%$ untuk ayam petelur. (Widodo, 2009). Oleh karena itu perlu dilakukan pencarian pakan alternative dan berkelanjutan. Pakan unggas harus mengandung semua nutrisi yang dibutuhkan untuk mendukung produksi dan pemeliharaan, sehingga dapat mengekspresikan potensi genetiknya.

Pakan alternative yang digunakan sekarang dalam menghadapi krisis pakan adalah pemanfaatan limbah pertanian dan perikanan lokal sebagai pakan sumber protein. Hal tersebut terkendala oleh kualitas yang rendah dan tidak tidak berkesinambungan karena tergantung dengan musim. Salah satu jenis bahan pakan yang dapat dijadikan sebagai sumber protein alternatif adalah Insekta karena protein tinggi, produksi tinggi dan tidak tergantung dengan musim sehingga dapat diproduksi secara terus-menerus.

Studi tentang pencarian pakan sumber protein alternatif dengan memfaatkan insekta sedang berkembang saat ini. Insekta mengandung protein yang lebih ekonomis dan ramah lingkungan serta memilki peran penting secara alamiah. Efeiensi konversi pakan insekta yang tinggi dan dapat diproduksi secara massal (Q. Li et al., 2011). Insekta juga tidak berkompetisi sebagai kebutuhan pangan untuk manusia sehingga sangat sesuai digunakan sebagai pakan ternak unggas. Salah satu jenis insekta yang dapat digunakan yaitu lalat hitam (Hermetia illucens).

Maggot lalat tentara hitam (Hermetia illucens) merupakan salah satu jenis insekta yang memenuhi persyaratan sebahai pakan sumber protein. Bahan pakan sebagai sumper protein yaitu bahan pakan yang mengandun protein kasar lebih dari 19\% (Huis, 2013; Nangoy et al., 2017). Insekta mengandung protein tinggi, ekonomis dan ramah lingkungan

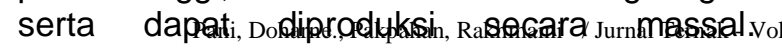
Disamping itu, tidak berkmpetisi dengan manusia , sehingga sangat sesuai dijadikan pakan sumber protein (Fauzi dan Sari, 2018). Maggot Hermetia illucens selain memiliki nutrisi yang tinggi, juga memiliki massa nutrisi yang memenuhi untuk dijadikan sebagai bahan pakan ungags (Fahmi et al.,2009). Maggot Hermetia illucens dapat mengubah zat organik menjadi biomassanya. Maggot memiliki keunggulan yaitu dapat diproduksi dalam berbagai ukuran sesuai dengan kebutuhan. Maggot memiliki organ penyimpanan yang disebut trophocytes yang berfungsi untuk menyimpan kandungan nutrien yang terdapat pada media kultur yang dimakannya (Subamia et al., 2010).
Berdasarkan hal tersebut maka penelitian ini dilakukan dengan menggunakan media yang berbeda bertujuan untuk mengoptimalkan produksi magoot meliputi massa protein, massa lemak kasar dan massa serat kasar.

\section{MATERI DAN METODE}

Penelitian ini dilaksanakn pada bulan April - Juli 2019. Pemeliharaan maggot lalat tentara hitam Hermetia illucens, Penelitan ini dilaksanakan di Program Studi Peternakan Unasman untuk pemeliharaan dan analisis nutrisi di laksanakan di Lab Kimia Pakan Fakultas Peternakan UNHAS.

Alat yang digunakan yaitu baskom, tali rapiah, kain kasha dan timbangan. Bahan yang digunakan yaitu feses ayam, ampas tahu, maggot Hermetia illucens.

Semua bahan untuk media tumbuh ditimbang dan dicampur yang beratnya $2,5 \mathrm{~kg}$. Kemudian setiap media tumbuh ditambahkan 1 gram telur Hermetia illucens dan ditumbuhkan selama 20 hari. Penelitian ini dirancang dengan menggunakan Rancangan Acak Lengkap (RAL) 3 perlakuan yaitu jenis media dan 3 ulangan. Secara keseluruhan menghasilkan 9 unit percobaan yaitu $3 \times 3$.

A0: ampas tahu $100 \%$

A1: ampas tahu $50 \%$ kotoran ayam $50 \%$

A2: ampas tahu $75 \%$ kotoran ayam $25 \%$

Data yang diperoleh dianalisis dengan menggunakann uji ANOVA menggunakan SPSS versi 24 dan uji lanjut Duncant apabila berbeda nyata.

\section{HASIL DAN PEMBAHASAN \\ Bahan kering}

Berdasarkan analisis sidik ragam media yang berbeda pada maggot lalat tentara hitam (Hermetia illucens) tidak berpengaruh nyata $(P>0.05)$ terhadap massa bahan kering

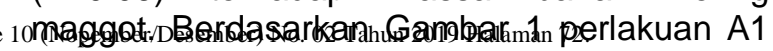
penggunaan media ampas tahu $75 \%$ dicampur feses ayam $25 \%$ menunjukkan massa bahan kering yang teringgi dan terendah yaitu perlakaun A0 media ampas tahu $100 \%$.

Produksi bahan kering maggot Hermetia illucens pada A0 (40.11g), A1 (43.82 g), dan A2 (41.34g). Rendahnya produksi bahan kering $A 0$ disebabkan kadar air media yang tinggi. Media yang digunakan pada A0 yaitu ampas tahu basah $100 \%$ dengan kadar air $85 \%$ sehingga maggot memiliki kadar air tinggi dan kadar bahan kering yang rendah. (Raharjo et al., 2016) menjelaskan bahwa semakin banyak nutrisi yang terkandung pada media tumbuh maka kandunggan nutrisi pada maggot akan tinggi. 
Gambar. Bahan Kering Lalat Tentara Hitam (Hermetia illucens) pada Media Pemeliharaan yang Berbeda $(\mathrm{g})$

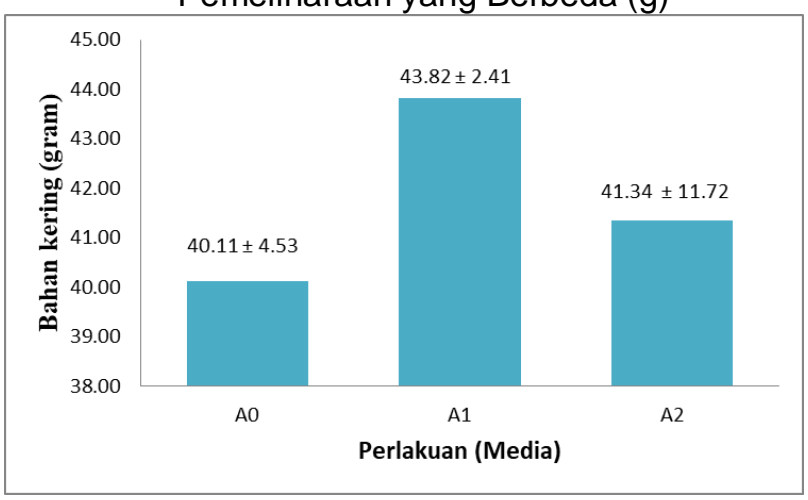

Keterangan : Huruf yang Berbeda pada Superscript Angka Rata-Rata menunjukkan Berbeda Nyata $(P<0.05)$.

Produksi bahan kering perlakuan A1 tinggi disebabkan kandungan bahan kering media dan mudah dicerna oleh maggot Hermetia illucens. Bahan kering yang tinggi pada media perlakuan A1 yaitu dari bahan organic hasil fermentasi mikroorganisme. Bahan organik hasil fermentasi berupa asam lemak terbang dan protein kasar dari media maupun dari enzim mikroorganisme. (Q. Li et al., 2011) Maggot Hermetia illucens mengubah nutrient dari media feses ternak menjadi protein dan lemak 10 jenis asam lemak telah terdeteksi, termasuk asam palmitat, asam oleat dan asam linolenat dan sebagainya. (Tomberlin et al., 2009) Individu yang diberi pakan kadar nutrisi rendah memiliki cadangan lipid yang lebih sedikit dibandingkan maggot dengan pakan nutrisi tinggi.

(Newton et al., 2005) menjelaskan fermentasi adalah proses perombakan bahan organik menjadi senyawa sederhana baik protein maupun lemak dalam kondiri anaerob dengan bantuan mikroorganisme. Jenis mikroorganisme yang berperan dalam proses perombakan yaitu bakteri, jamur dan larva serangga (family: Chaliforide, Mucidae, Stratiomydae). (Fahmi et al., 2009) agen perombak pada limbah-limbah hewani yang sering ditemukan yaitu larva serangga Dieptra dari famili Challifora. Larva dari family Stratiomydae, Genus Hermetia, spesies Hermetia illucens.

\section{Protein Kasar}

Protein kasar maggot lalat tentara hitam Hermetia illucens dengan lama pemeliharaan yang berbeda disajikan pada Gambar 2 .
Berdasarkan analisis sidik ragam media yang berbeda maggot lalat tentara hitam (Hermetia illucens) tidak berpengaruh nyata $(P>0.05)$ pada massa protein kasar maggot. Berdasarkan Gambar dibawah ini perlakuan A1 penggunaan media ampas tahu $75 \%$ dicampur feses ayam $25 \%$ menunjukkkan massa bahan kering yang tertinggi dan terendah yaitu perlakuan A0 media ampas tahu $100 \%$.

Produksi protein kasar maggot Hermetia illucens pada A0 (15.83g), A1 (18.29 g) dan A2 $(17.89 \mathrm{~g})$. Massa protein kasar berbanding lurus dengan massa bahan kering maggot. Hal tersebut menunjukkan bahwa massa bahan kering mempengaruhi protein maggot. Tingginya protein kasar maggot pada perlakuan A1 bersumber dari asam amino media yang terfermentasi secara alami. (Cicilia dan Susila, 2012). Jenis asam amino pada maggot Hermetia illucens yaitu asam glutamat, asam aspartat, alanin, tirosin, valin, lisin dan leusin. (Suciati and Faruq, 2017) Komposisi media mempunyai pengaruh yang cukup signifikan terhadap kadar maggot yang dihasilkan, kandungan protein maggot BSF sangat ditentukan oleh kandungan protein media tumbuhnya.

Gambar . Protein Kasar Maggot Lalat Tentara Hitam (Hermetia illucens) dengan Media yang Berbeda (gram).

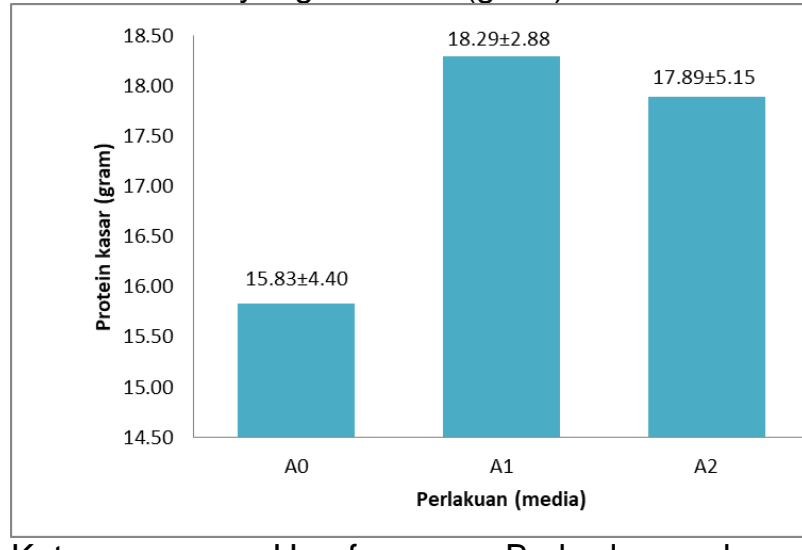

Keterangan : Huruf yang Berbeda pada Superscript Angka Rata-Rata, Menunjukkan Berbeda Nyata $(\mathrm{P}<0.05)$

Larva Hermetia illucens memilki enzim protease dalam system pencernaannya, sehingga mampu mencerna berbagai jenis bahan organik kemudian merombaknya menjadi protein (Kim et al., 2011). Kandung nutrisi pakan yang diberikan pada mggot, kurang lebih biomassa larva perpupa. Penyimpanan protein dan karbohidrat terdapat pada proporsi massa pada eklosi dewasa ditandai dengan pertumbuhan somatik. Proporsi protein dan karbohidrat yang disimpan 
dalam tubuh tidak berbeda dengan pakan perlakuan yang diberikan (Hahn, 2005).

\section{Lemak Kasar}

Lemak kasar maggot lalat tentara hitam Hermetia illucens dengan media yang berbeda dapat dilihat pada Gambar dibawah ini. Berdasarkan sidik ragam penggunaan media dengan penambahan feses ayam signifikan mempengaruhi turunnya massa lemak kasar pada maggot lalat tentara hitam (Hermetia illucens) berpengaruh sangat nyata $(P<0.05)$. Gambar 3 perlakuan A0 tidak berbeda nyata lebih tinggi dengan $A 1(P<0.05)$, tetapi $A 0$ dan A1 nyata lebih tinggi dari $A 2$.

Penelitian ini menunjukkan bahwa semakin tingginya penggunaan media ampas tahu maka kadar lemak kasar maggot semakin tinggi. Lemak yang terdapat pada maggot berupa asam lemak dari media yang dikonsumsi dengan bantuan enzim lipase yang terdapat pada maggot Hermetia illucens. (Fahmi et al., 2009). Agen perombak limbah hewani yang sering ditemukan adalh larva serangga Dieptra dari famili Challifora, larva serangga dari Limbah-limbah hewani agen perombak yang sering ditemukan adalah larva serangga Diptera dari famili Challifora. Larva serangga dari famili: Stratiomydae, Genus: Hermetia, spesies: Hermetia illucens.

Gambar . Lemak kasar Maggot Lalat Tentara Hitam (Hermetia illucens) dengan media yang Berbeda (gram)

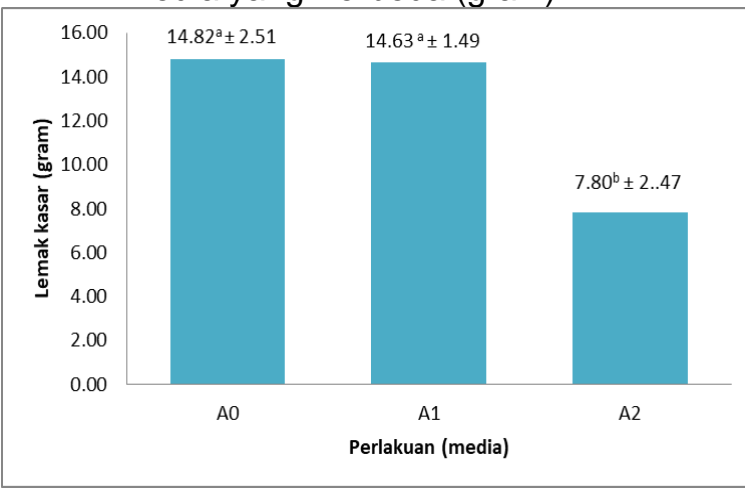

Keterangan : Huruf yang Bebeda pada Superscript Angka Rata-Rata, Berbeda Nayata $(P<0.05)$.

Enzim lipase yang terdapat pada larva Hermetia illucens berfungsi merubah serat, karbohidrat dan lemak menjadi asam lemak terbang untuk dijadikan caadangan energy prapupa. (Hakim et al., 2017). Keberadaan enzim amylase pada pencernaan larva Hemetia illucens sehingga semua bahan organik yang dimakannya dapat dirombak menjadi lemak dan kalori.

\section{Serat Kasar}

Hasil uji Duncan menunjukkan bahwa perlakauan $A 0$ nyata lebih rendah $(P<0.05)$ dengan $A 2$ dan sama dengan $A 1$, akan tetapi A1 sama dengan A2. Massa serat kasar pada perlakuan ini yaitu A0 (2.9 g), A1 (4.62 g) dan A2 $(5.55 \mathrm{~g})$.

Lignin yang terdapat di dalamnya merupakan jenis serat yang susah diubah menjadi asam lemak. (Kim et al., 2011) larva lalat tentara hitam (Hermetia illucens) di saluran pencernaannya terdapat mekroorganisme pencerna lignin diubah menjadi selulosa sumebr energy untuk maggot. (W. Li et al., 2015; Yu et al., 2011) lignicellulose mengubah lignin menjadi gula sederhana yang merupakan enzim yang dihasilkan oleh larva lalat tentara hitam (Hermetia illucens).

Gambar. Serat kasar Maggot Lalat Tentara Hitam (Hermetia illucens) dengan media yang Berbeda (gram)

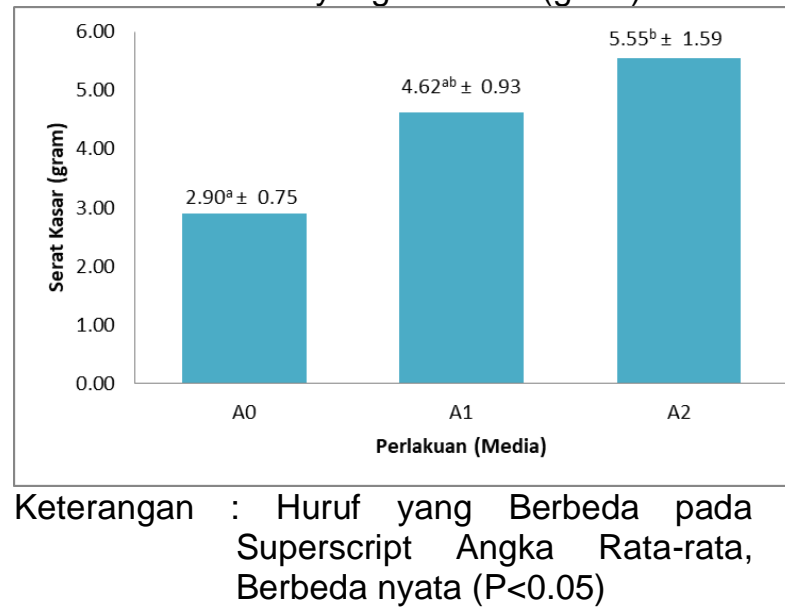

\section{Kesimpulan}

Berdasarkan hasil dan pembahasan dapat disimpulkan bahwa paling optimal produksi maggot lalat tentara hitam Hermetia illucens dari kualitas maupun kuantitas untuk dijadikan pakan ternak adalah perlakuan A1 dengan massa bahan kering $43.82 \mathrm{~g}$ dengan protein kasar $18.29 \mathrm{~g}$ dan lemak kasar $14.63 \mathrm{~g}$ serta serat kasar $4.62 \mathrm{~g}$.

\section{DAFTAR PUSTAKA}

Cicilia, Asi Pebrina, and Nyata Susila. 2012. "Potential of Tofu Dregs on The Production of Maggot ( Hermetia lllucens ) as a Source of Protein of Fish Feed." Jurnal Anterior 18 (1): 40-48.

Fahmi, R., S. Melta, W Hem, and I W.Subamia. 2009. "Maggot Potential to Increase Growth and Improve Health Status of Fish." J. Ris. Akuakultur 4 (2): 221-32. 
Fauzi, R.U.A., and E.R.N. Sari. 2018. "Business Analysis of Maggot Cultivation as a Catfish Feed Alternative." Industria: Jurnal Teknologi Dan Manajemen Agroindustri 7 (1): 39-46.

Hahn, Daniel A. 2005. "Larval Nutrition Affects Lipid Storage and Growth , but Not Protein or Carbohydrate Storage in Newly Eclosed Adults of the Grasshopper Schistocerca Americana." Journal Insect Physiology 51: 1210-19. https://doi.org/10.1016/j.jinsphys.2005.06. 011.

Hakim, Arif R, Agus Prasetya, and Himawan T B M Petrus. 2017. "Perikanan The Potential of Hermetia Illucens Larvae as Reducer of Industrial Fish Processing Waste." Jurnal Peternakan Universitas Gajah Mada 19 (1): 39-44.

Huis, AVan A. 2013. "Potential of Insects as Food and Feed in Assuring Food Security." Annu Rev Entomol 58: 563-83.

Kim, W, S Bae, K Park, S Lee, Y Choi, S. Han, and Y. Koh. 2011. "Biochemical Characterization of Digestive Enzymes in the Black Soldier Fly, Hermetia Illucens (Diptera: Stratiomyidae)." J. of Asia-Pasific Entomology 14: 11-14.

Li, Qing, Longyu Zheng, Ning Qiu, Hao Cai, Jeffery K Tomberlin, and Ziniu Yu. 2011. "Bioconversion of Dairy Manure by Black Soldier Fly ( Diptera: Stratiomyidae) for Biodiesel and Sugar Production Bioconversion of Dairy Manure by Black Soldier Fly ( Diptera: Stratiomyidae ) for Biodiesel and Sugar Production." WASTE MANAGEMENT, no. February. https://doi.org/10.1016/j.wasman.2011.01. 005.

Li, W, M Li, L Zheng, Y Liu, Y Zhang, and Zl Yu. 2015. "Simultaneous Utilization of Glucose and Xylose for Lipid Accumulation in Black Soldier Fly." Biotechnology for Biofuels 8 (117).

Nangoy, M.M, M.E.R Montong, W Utiah, and M.N. Regar. 2017. "Utilization of Manure Flour from the Degradation of Black Fly Larva (Hermetia Illucens L) on the Performance of Layer Phase Kampung Chicken." Jurnal Zootek 37 (2): 370377. and G. Burtle R. 2005. "Using the Black Soldier Fly, Hermetia Illucens, as a ValueAdded Tool for the Management of Swine Manure. Report for The Animal and Poultry Waste Management Cente." North Carolina.

Q. Li, L, N Zheng, H Qiu, J Cai, Tomberlin, and Z. Yu. 2011. "Bioconversion of Dairy Manure by Black Soldier Fly (Diptera: Stratiomyidae) for Biodiesel and Sugar Production." J.Wasman 31 (6): 13161320.

Raharjo, Eka Indah, Rachimi, and Arief Muhammad. 2016. "Dregs Use Tofu\& Feses Chicken to Increase Productionlarva (Hermetia Illucens)." Jurnal Ruaya 4 (1): 33-38.

Subamia, I W, B. Nur, A. Musa, and R. V Kusumah. 2010. "Color Quality Improvement of Red Rainbow Fish (Glossolepis Incisus,Weber1907) through Carotenoids Source Enrichment of Shrimp Head Meal in Feed." Jurnal Iktiologi Indonesia 10 (1): 1-9.

Suciati, R., and Faruq. 2017. "The Effectiveness of Maggots Hermetia Illucens Growth Media (Black Solider Flies) as a Solution for Organic Waste Utilization." Jurnal Biologi Dan Pendidikan Biologi 8 (1): 8-13.

Tomberlin, Jeffery K, Peter $\mathrm{H}$ Adler, Heidi M Myers, Jeffery $\mathrm{K}$ Tomberlin, and Peter $\mathrm{H}$ Adler. 2009. "Development of the Black Soldier Fly ( Diptera: Stratiomyidae ) in Relation to Temperature Development of the Black Soldier Fly ( Diptera: Stratiomyidae ) in Relation to Temperature" 38 (3): 930-34.

Widodo, Wahyu. 2009. "Ketahanan Pakan Unggas Di Tengah Krisis Pangan." Jurnal UMM 12 (1): 107-25.

Yu, G, P Cheng, Y Chen, Y Li, Z Yang, and Y Chen. 2011. "Inoculating Poultry Manure with Companion Bacteria Influences Growth and Development of Black Soldier Fly (Diptera: Stratiomyidae) Larvae." Environmental Entomology 40 (1): 30-35.

Newton, L, C Sheppard, D.W Watson, Dove, 